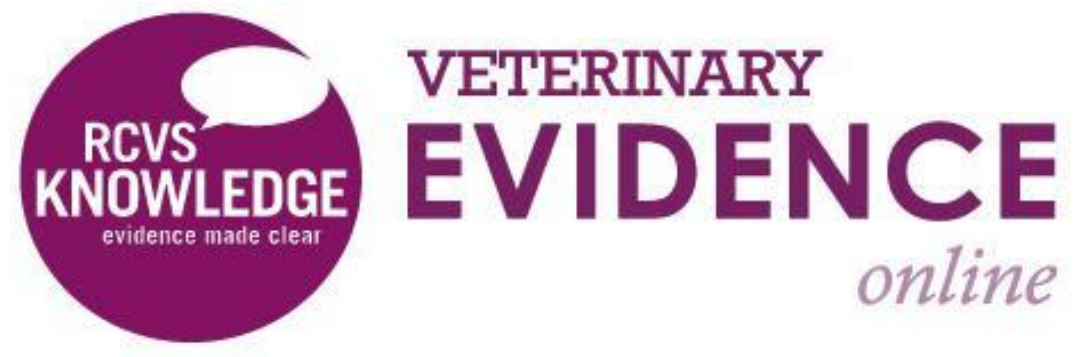

\title{
In Dogs With Pyothorax Does Medical Management Alone, Invasive Medical Management, or Surgical Management Result in Better Long-term Outcome?
}

\section{A Knowledge Summary by}

Barnaby Dean BVSc, MRCVS ${ }^{1^{*}}$

Sophie Adamantos BVSc, CertVA, DACVECC, DipECVECC, MRCVS, FHEA ${ }^{1^{*}}$

\footnotetext{
1 University of Bristol, Senate House, Tyndall Ave, Bristol BS8 1TH

*orresponding Author (barneydean@gmail.com)
}

ISSN: 2396-9776

Published: 05 May 2017

in: Vol 2, Issue 2

DOI: http://dx.doi.org/10.18849/ve.v2i2.87

Reviewed by: Shailen Jasani (MA VETMB MRCVS DACVECC) and Bruce Smith (BVSc MS FANZCVS DACVS) 
KNOWLEDGE SUMMARY

\section{Clinical bottom line}

Currently available literature on canine pyothorax management is low quality, so it is difficult to draw meaningful conclusions from it. With this in mind, however, the literature does suggest that invasive medical management (thoracic drainage and lavage via in-dwelling thoracostomy tubes, and antimicrobial therapy) and surgical management (in conjunction with antimicrobial therapy) of canine pyothorax provide better long-term survival rates compared to non-invasive medical management (antimicrobial therapy, with or without thoracocentesis) alone. More definitive conclusions cannot be made until higher quality evidence (prospective, randomised, blinded) is available on the topic.

\section{Question}

In dogs with pyothorax does medical management alone, invasive medical management, or surgical management result in better long-term outcome?

\section{Clinical Scenario}

A five-year old male neutered English Springer Spaniel is presented with a two-day history of progressive dyspnea and exercise intolerance. Clinical examination reveals tachypnea, bilaterally reduced heart sounds, and pyrexia. Basic haematology and biochemistry findings are consistent with infection, thoracic radiography findings are consistent with bilateral pleural effusion, and thoracocentesis findings are consistent with pyothorax. Should the patient be treated medically or surgically?

\section{Summary of the evidence}

\begin{tabular}{|c|c|}
\hline Population: & $\begin{array}{l}\text { Nineteen dogs with pyothorax confirmed by either the presence of } \\
\text { intracellular bacteria on cytological examination, or a positive } \\
\text { bacterial culture of pleural fluid, that underwent medical } \\
\text { management, early surgery (less than } 48 \text { hours following } \\
\text { hospitalisation) or late surgery (more than } 48 \text { hours following } \\
\text { hospitalisation). }\end{array}$ \\
\hline Sample size: & Nineteen dogs. \\
\hline Intervention details: & $\begin{array}{l}\text { - Thirteen out of } 19 \text { dogs had bilateral thoracostomy tubes placed } \\
\text { (invasive medical management), and intermittent pleural lavage } \\
\text { (with } 19.0+/-12.1 \mathrm{ml} / \mathrm{kg} \text { warmed crystalloid solution) and } \\
\text { drainage was performed two-to-four times daily. } \\
\text { - Five dogs were treated surgically ( } 11 \text { median sternotomies, one } \\
\text { lateral thoracotomy). } \\
\text { - One dog was treated as an outpatient with antibiotics following } \\
\text { thoracocentesis. } \\
\text { - Antibiotics used were most commonly enrofloxacin and } \\
\text { ampicillin for } 10 \text { to } 120 \text { days (median } 33 \text { days). }\end{array}$ \\
\hline Study design: & Retrospective single-centre data analysis. \\
\hline
\end{tabular}




\begin{tabular}{|c|c|}
\hline Outcome studied: & $\begin{array}{l}\text { Overall cost of treatment, survival rate, and duration of } \\
\text { hospitalisation. }\end{array}$ \\
\hline $\begin{array}{l}\text { Main findings: } \\
\text { (relevant to PICO question): }\end{array}$ & $\begin{array}{l}\text { - Seven patients were in the medical treatment group, five were } \\
\text { in the early surgery group, and seven were in the late surgery } \\
\text { group. } \\
\text { Median cost of treatment was } f 1933 \text { (range } f 256-2386 \text { ) for the } \\
\text { medical group, } f 2930 \text { (range } f 2549-5246 \text { ) for the early surgery } \\
\text { group, and } f 6059 \text { (range } f 3783-7208 \text { ) for the late surgery group. } \\
\text { - All patients in all patient groups survived to discharge and none } \\
\text { had experienced recurrence of pyothorax by six months } \\
\text { following discharge. }\end{array}$ \\
\hline Limitations: & $\begin{array}{l}\text { - The study is retrospective, with a small number of cases. } \\
\text { - The results cover a } 10 \text {-year study period. } \\
\text { - The study was performed on data from a single referral teaching } \\
\text { hospital. } \\
\text { - Some patients (number not stated) were converted to the } \\
\text { surgical group from the medical group which adds bias to the } \\
\text { results. } \\
\text { - The authors' exclusion criteria excluded dogs that died within } \\
\text { 24-hours of hospitalisation. } \\
\text { - The severity of clinical signs and intensity of each treatment are } \\
\text { not discussed or compared between patients groups. } \\
\text { - Little attention is given to specific treatment protocols. }\end{array}$ \\
\hline
\end{tabular}

\begin{tabular}{|c|c|}
\hline \multicolumn{2}{|l|}{ Boothe (2010) } \\
\hline Population: & $\begin{array}{l}\text { Forty-six dogs with pyothorax confirmed by either the presence of } \\
\text { intracellular bacteria in pleural fluid or tissue, bacteria recovered via } \\
\text { culture of pleural fluid, or both, that underwent either non-surgical } \\
\text { non-invasive, non-surgical invasive or surgical treatment. }\end{array}$ \\
\hline Sample size: & Forty-six dogs. \\
\hline Intervention details: & $\begin{array}{l}\text { - All dogs were treated with at least one antibiotic, plus } \\
\text { thoracocentesis (non-invasive medical, } n=7 \text { ), a thoracostomy } \\
\text { tube (invasive medical, 26) with or without pleural lavage and } \\
\text { heparin, or a thoracotomy (surgical, } 13 \text { ) and thoracostomy tube } \\
\text { with or without pleural lavage and heparin. } \\
\text { Most commonly used empirical (pre-culture and sensitivity) } \\
\text { antibiotics were trimethoprim-sulfonamide ( } n=30 \text { ), enrofloxacin } \\
\text { (24), amoxicillin (23), ampicillin (20), and penicillin (10). }\end{array}$ \\
\hline Study design: & Retrospective single-centre case series. \\
\hline Outcome studied: & $\begin{array}{l}\text { Short-term (survival to discharge) and long-term (survival to } 12 \\
\text { months following discharge) survival rate. }\end{array}$ \\
\hline $\begin{array}{l}\text { Main findings: } \\
\text { (relevant to PICO question): }\end{array}$ & $\begin{array}{l}\text { - Treatment was non-surgical non-invasive in sevenpatients, non- } \\
\text { surgical invasive in } 26 \text { patients, and surgical in } 13 \text { patients. } \\
\text { - Overall short-term survival rate was } 74 \% \text { ( } n=34) \text {. Short-term } \\
\text { survival was } 29 \% \text { (2) for non-surgical non-invasive patients, } 77 \%\end{array}$ \\
\hline
\end{tabular}




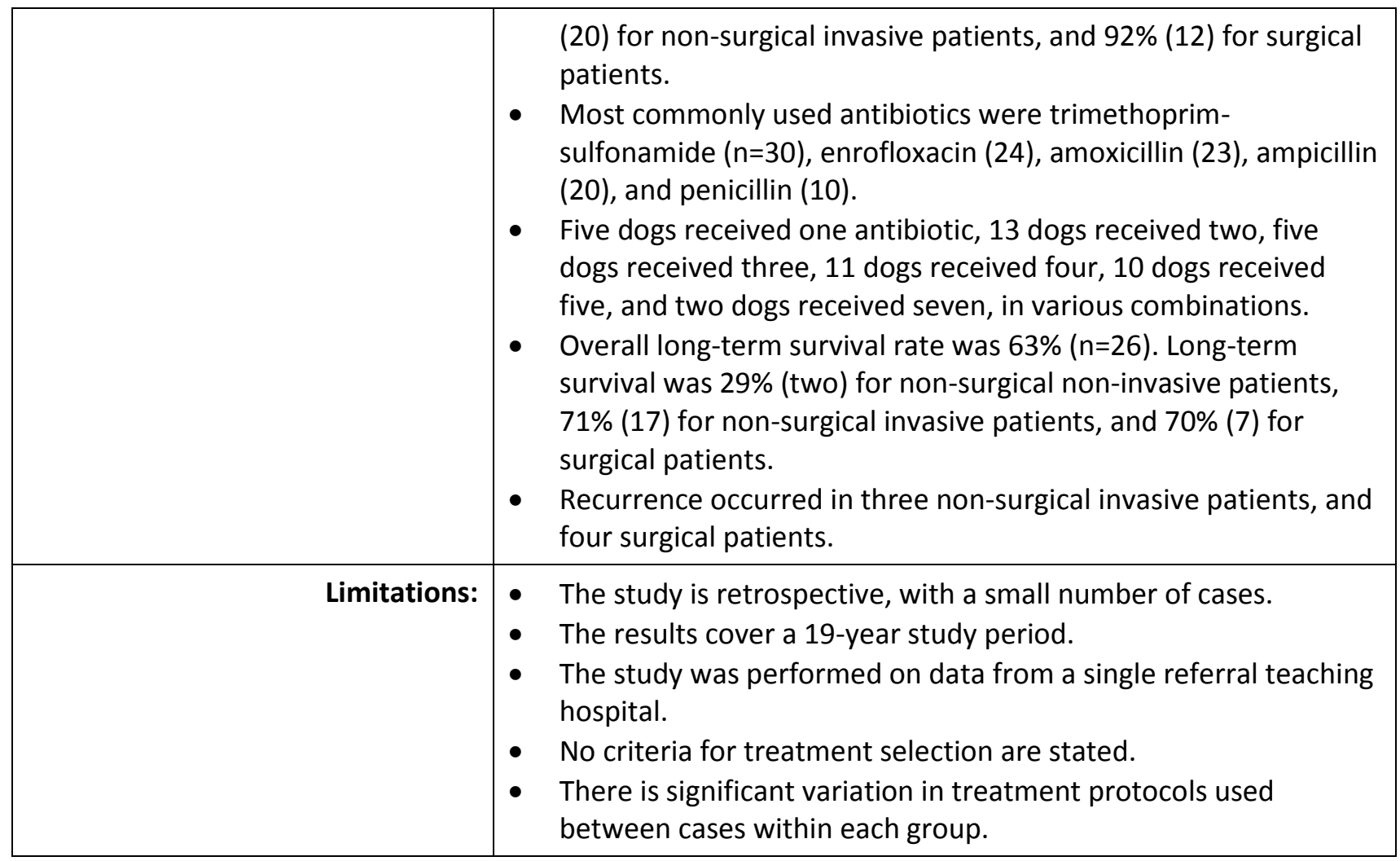

\begin{tabular}{|c|c|}
\hline \\
\hline \multicolumn{2}{|r|}{$\begin{array}{l}\text { Fifty cases ( } 36 \text { dogs and } 14 \text { cats) with confirmed pyothorax were } \\
\text { evaluated from five referral institutions in the UK and Ireland. }\end{array}$} \\
\hline Sample size: & Thirty-six dogs and 14 cats. \\
\hline Intervention details: & $\begin{array}{l}\text { - Seven dogs were treated surgically. } \\
\text { - Thoracostomy tubes (invasive medical management) were } \\
\text { placed in } 48 \text { of the } 50 \text { cases. Forty-two of these underwent } \\
\text { pleural lavage using } 0.5-6 \mathrm{~L} \text { fluid (either isotonic saline, isotonic } \\
\text { saline with intrapleural antibiotic solutions (ampicillin and/or } \\
\text { metronidazole), or compound sodium lactate. } \\
\text { - All animals were given antibiotic therapy. Most commonly used } \\
\text { agents were metronidazole, ampicillin, } \\
\text { andenrofloxacin/marbofloxacin. }\end{array}$ \\
\hline Study design: & Retrospective multi-centre case series. \\
\hline Outcome studied: & $\begin{array}{l}\text { Complete resolution of pyothorax following the first treatment after } \\
\text { presentation, with no evidence of recurrence at the time of re- } \\
\text { evaluation. }\end{array}$ \\
\hline $\begin{array}{l}\text { Main findings: } \\
\text { (relevant to PICO question): }\end{array}$ & $\begin{array}{l}\text { - Six dogs died during the study period, of which one was treated } \\
\text { - } \quad \text { All remaically and five were treated medically. } \\
\text { end of the five-year study period. } \\
\text { - No patients required surgical treatment after medical therapy. } \\
\text { - Two surgically-treated cases from which no foreign bodies could } \\
\text { be found did not have chest drains placed. }\end{array}$ \\
\hline
\end{tabular}




\begin{tabular}{|c|c|}
\hline & $\begin{array}{l}\text { - Survival beyond 48-hours after presentation is a positive } \\
\text { prognostic indicator for canine pyothorax. }\end{array}$ \\
\hline Limitations: & $\begin{array}{l}\text { - The study is retrospective, with a small number of cases. } \\
\text { - The results cover a five-year period. } \\
\text { - The study was performed using data from five referral teaching } \\
\text { hospitals. } \\
\text { - Data is poorly presented, preventing direct comparisons } \\
\text { between medically and surgically managed dogs and cats. }\end{array}$ \\
\hline
\end{tabular}

\begin{tabular}{|c|c|}
\hline \\
\hline Nino dorc with thoracir omnyma of untenon oririn & Nine dogs with thoracic empyema of unknown origin. \\
\hline Sample size: & Nine dogs. \\
\hline Intervention details: & $\begin{array}{l}\text { - All dogs were treated with antibiotic therapy and intermittent } \\
\text { thoracic drainage. } \\
\text { - Five dogs had surgery performed following unsuccessful invasive } \\
\text { medical management. }\end{array}$ \\
\hline Study design: & Retrospective single-centre case series. \\
\hline Outcome studied: & Patient survival. \\
\hline $\begin{array}{l}\text { Main findings: } \\
\text { (relevant to PICO question): }\end{array}$ & $\begin{array}{l}\text { - Two dogs were euthanised during the early treatment phase. } \\
\text { - Seven dogs appeared clinically well within two to three weeks } \\
\text { - In five dogs (three medical, two surgical cases) there had not } \\
\text { been any sign of recurrence three-to-nine (mean five) years } \\
\text { following treatment. } \\
\text { - The remaining two dogs either died despite attempted further } \\
\text { management of recurrence, or were euthanised after a thoracic } \\
\text { mass was identified. }\end{array}$ \\
\hline Limitations: & $\begin{array}{l}\text { - The study is retrospective, with a small number of cases. } \\
\text { - The study is } 20 \text { years old. } \\
\text { - Cases are from a single hospital. } \\
\text { - The results cover a five year period, with some cases reported } \\
\text { from } 29 \text { years ago. } \\
\text { - There is minimal statistical analysis. }\end{array}$ \\
\hline
\end{tabular}

\begin{tabular}{|r|l|}
\hline \multicolumn{2}{|l|}{ Johnson (2006) } \\
\hline Population: & $\begin{array}{l}\text { Fifteen dogs with pyothorax who were treated successfully with } \\
\text { medical management and a single thoracocentesis. }\end{array}$ \\
\hline Sample size: & Fifteen dogs. \\
\hline Intervention details: & $\begin{array}{l}\text { Unilateral thoracocentesis (non-invasive medical management) was } \\
\text { performed in all 15 cases in conjunction with antibiotic therapy. }\end{array}$ \\
\hline Study design: & Retrospective single-centre case series. \\
\hline Outcome studied: & $\begin{array}{l}\text { Survival and lack of relapse as cessation of antibiotic therapy (six to } \\
16 \text { weeks, mean nine weeks) and long-term follow up (mean } 27\end{array}$ \\
\hline &
\end{tabular}




\begin{tabular}{|c|c|}
\hline & months). \\
\hline $\begin{array}{l}\text { Main findings: } \\
\text { (relevant to PICO question): }\end{array}$ & $\begin{array}{l}\text { - One patient was excluded because a fluid-filled mass (abscess) } \\
\text { was identified and surgery was performed. } \\
\text { - Duration of clinical signs prior to referral was three days to } \\
\text { seven months, median four weeks. } \\
\text { - All dogs were considered clinically normal by owners at } \\
\text { cessation of antibiotics. } \\
\text { - There was no relapse, and all dogs were considered clinically } \\
\text { normal at long-term follow up. }\end{array}$ \\
\hline Limitations: & $\begin{array}{l}\text { - The study is retrospective, with a small number of cases. } \\
\text { - The results cover a seven-year period. } \\
\text { - The results are from a single referral hospital. } \\
\text { - Only one of the } 15 \text { cases had concurrent thoracic pathology } \\
\text { identified (adhesions). } \\
\text { - There is no explanation of how long-term assessment is } \\
\text { performed. } \\
\text { - Only seven effusions were culture positive, so antibiotic therapy } \\
\text { was empiricalrather than based on culture results in eight cases. }\end{array}$ \\
\hline
\end{tabular}

\begin{tabular}{|c|c|}
\hline \\
\hline \multicolumn{2}{|r|}{ Dogs with pyothorax. } \\
\hline Sample size: & Not applicable. \\
\hline Intervention details: & Not applicable. \\
\hline Study design: & Literature review. \\
\hline Outcome studied: & Not applicable. \\
\hline $\begin{array}{l}\text { Main findings: } \\
\text { (relevant to PICO question): }\end{array}$ & $\begin{array}{l}\text { - Pyothorax in patients treated with antibiotics alone or no } \\
\text { treatment is often fatal. } \\
\text { - The primary complication of various treatments is recurrence of } \\
\text { pyothorax. } \\
\text { - } \text { mo definitive algorithms are presented by previous studies for } \\
\text { - There is significant treatment failure in canine pyothorax. } \\
\text { - } \quad \text { on randomised, prospective studies are available. } \\
\text { - One-hundred percent success has been reported in a case series } \\
\text { thoracocentesis was performed, followed by antibiotic therapy } \\
\text { for a minimum of six weeks. } \\
\text { - Repeated thoracic lavage and draining via indwelling thoracic } \\
\text { drains is suggested by multiple studies. } \\
\text { Of six cases of canine pyothorax managed surgically in one } \\
\text { study, surgery was indicated as a result of: diagnostic imaging } \\
\text { results suggestive of a foreign body in three cases, draining sinus } \\
\text { in one case, and pleural or mediastinal masses in two cases. }\end{array}$ \\
\hline Limitations: & $\begin{array}{l}\text { - The review adds nothing new to the literature. } \\
\text { - Very few of the reviewed papers directly compare medical and } \\
\text { surgical management of canine pyothorax. }\end{array}$ \\
\hline
\end{tabular}




\begin{tabular}{|c|c|}
\hline \\
\hline \multicolumn{2}{|r|}{ Dogs and cats with pyothorax. } \\
\hline Sample size: & Not applicable. \\
\hline Intervention details: & Not applicable. \\
\hline Study design: & Literature review. \\
\hline Outcome studied: & Not applicable. \\
\hline $\begin{array}{l}\text { Main findings: } \\
\text { (relevant to PICO question): }\end{array}$ & $\begin{array}{l}\text { - The prognosis for pyothorax is highly variable, and the argument } \\
\text { of medical versus surgical therapy has yet to be decided. } \\
\text { - Mortality rates vary from } 0 \% \text { (in both non-invasive and invasive } \\
\text { medical case series) to } 42 \% \text { (in a combined invasive medical and } \\
\text { surgical case series. } \\
\text { - Recurrence rates are highly variable, but thought to be higher } \\
\text { for Actinomyces spp or Nocardia spp infections. } \\
\text { - Thoracoscopy should be considered in the future for both } \\
\text { diagnostic and treatment purposes. }\end{array}$ \\
\hline Limitations: & $\begin{array}{l}\text { - The review adds nothing new to the literature. } \\
\text { - Very few of the reviewed papers directly compare medical and } \\
\text { surgical management of canine pyothorax. }\end{array}$ \\
\hline
\end{tabular}

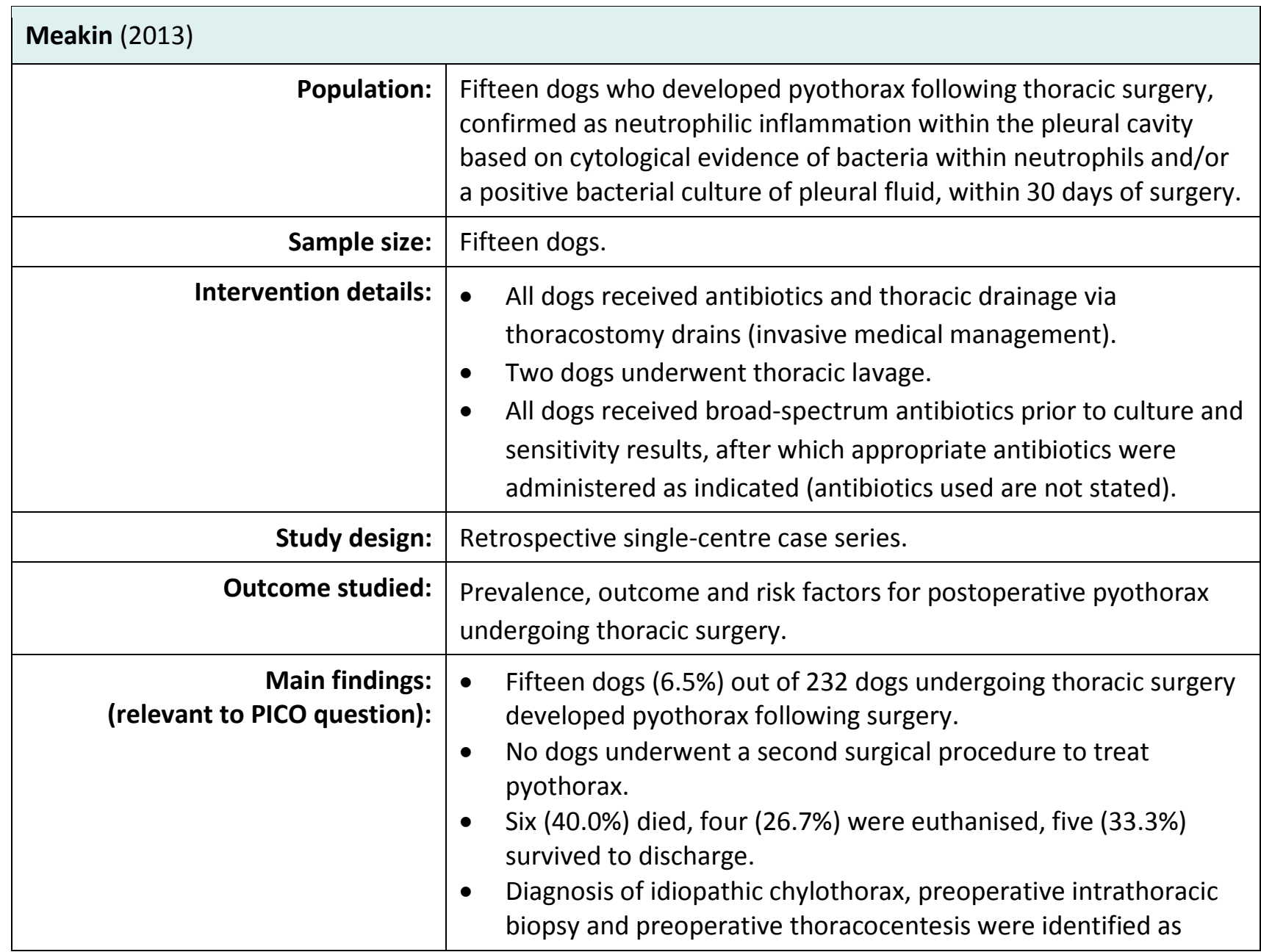




\begin{tabular}{|l|l|}
\hline & $\begin{array}{l}\text { independent risk factors for developing postoperative } \\
\text { pyothorax. }\end{array}$ \\
\hline Limitations: & $\begin{array}{l}\text { - The study is retrospective, with a small number of cases. } \\
\text { - }\end{array}$ \\
- Long-term follow-up is not available for all cases. \\
Patients were suffering from a wide-range of concurrent \\
pathology.
\end{tabular}

\begin{tabular}{|c|c|}
\hline \multicolumn{2}{|l|}{ Mellanby (2002) } \\
\hline Population: & Eighty-one dogs with pleural and mediastinal effusions. \\
\hline Sample size: & Eighty-one. \\
\hline Intervention details: & $\begin{array}{l}\text { Dogs were treated either with placement of chest drains (invasive } \\
\text { medical management) and pleural lavage at least twice daily for five } \\
\text { to seven days, and were administered broad spectrum antibiotics } \\
\text { (antibiotics used not stated) for between four and eight weeks, or } \\
\text { with surgery. }\end{array}$ \\
\hline Study design: & Retrospective single-centre case series. \\
\hline Outcome studied: & Disease free survival time. \\
\hline $\begin{array}{l}\text { Main findings: } \\
\text { (relevant to PICO question): }\end{array}$ & $\begin{array}{l}\text { - Thirteen of } 81 \text { cases were suffering from pyothorax. } \\
\text { - Treatment was attempted in } 11 \text { of the } 13 \text { cases. } \\
\text { - Three of these } 11 \text { cases died either during the placement of } \\
\text { chest drains or within } 48 \text { hours of exploratory thoracotomy. } \\
\text { initial treatment, and one dog died five weeks following surgery. } \\
\text { - Five of the eight dogs who were treated were managed by } \\
\text { placement of chest drains which were lavaged at least twice } \\
\text { daily for between five and seven days and were administered } \\
\text { broad spectrum antibiotics for between four and eight weeks. } \\
\text { - The three other dogs were treated surgically. }\end{array}$ \\
\hline Limitations: & $\begin{array}{l}\text { - The study is retrospective, with only a small number of cases } \\
\text { suffering from pyothorax. } \\
\text { - Cases are taken from a single hospital. } \\
\text { - } \text { Cases cover an eight year period. } \\
\text { - The study does not aim to directly compare medical and surgical } \\
\text { management of pyothorax, so data (including details or medical } \\
\text { management) and comparisons are limited. }\end{array}$ \\
\hline
\end{tabular}

Piek (2000)

Population: $\quad$ Nine dogs with pyothorax diagnosed through history, physical 


\begin{tabular}{|c|c|}
\hline & $\begin{array}{l}\text { examination, and radiographic and/or ultrasonographic examination } \\
\text { of the thorax. }\end{array}$ \\
\hline Sample size: & Nine dogs. \\
\hline Intervention details: & $\begin{array}{l}\text { - After culture and sensitivity, all dogs were treated with } \\
\text { antibiotics: either co-amoxyclav alone ( } \mathrm{n}=6), \text { co-amoxyclav and } \\
\text { enrofloxacin (1), metronidazole (1), co-amoxyclav and } \\
\text { metronidazole (1). } \\
\text { - All dogs were also treated with thoracic drains (invasive medical } \\
\text { management), and administered thoracic lavage for seven to } 12 \\
\text { days (median nine days). }\end{array}$ \\
\hline Study design: & Retrospective single-centre case series. \\
\hline Outcome studied: & $\begin{array}{l}\text { Disease free survival at four week follow up examination, seven } \\
\text { week follow up examination, and client telephone contact at least six } \\
\text { months following hospitalisation. }\end{array}$ \\
\hline $\begin{array}{l}\text { Main findings: } \\
\text { (relevant to PICO question): }\end{array}$ & $\begin{array}{l}\text { - At a four week follow-up all dogs were free of clinical signs, and } \\
\text { clinical examination was unremarkable. } \\
\text { Thoracic radiography was unremarkable in three dogs at four } \\
\text { weeks. } \\
\text { - In six of the dogs, pleural lines and small amounts of pleural fluid } \\
\text { were still evident at four weeks. Five of these dogs were } \\
\text { available for clinical examination and thoracic radiography three } \\
\text { weeks later, which were unremarkable. } \\
\text { In eight dogs, follow up client telephone contact revealed no } \\
\text { reported relapse. }\end{array}$ \\
\hline Limitations: & $\begin{array}{l}\text { - The study is retrospective, with a small number of cases. } \\
\text { - The study is } 17 \text { years old. } \\
\text { - Cases are from a single hospital. } \\
\text { - There is minimal statistical analysis. } \\
\text { - Underlying causes are not discussed. }\end{array}$ \\
\hline
\end{tabular}

\begin{tabular}{|r|l|}
\hline \multicolumn{2}{|l|}{ Robertson (1983) } \\
\hline Population: & $\begin{array}{l}\text { Twenty-two dogs with thoracic empyema confirmed by radiographic } \\
\text { demonstration of thoracic free fluid and bacterial identification by } \\
\text { examination of thoracic aspirates. }\end{array}$ \\
\hline Sample size: & Twenty-two dogs. \\
\hline Intervention details: & $\begin{array}{l}\text { Dogs were treated with antibiotics and either thoracocentesis (non- } \\
\text { invasive medical management), chest drain placement (invasive } \\
\text { medical management), or surgery. }\end{array}$ \\
\hline Study design: & Retrospective single-centre case series. \\
\hline Outcome studied: & Survival time, up to time of writing. \\
\hline Main findings: & $\begin{array}{l}\text { Sixteen patients survived to discharge, of which two were } \\
\text { euthanised (one treated non-invasive medically, the other } \\
\text { treated invasive medically) within four months due to } \\
\text { recurrence of signs. }\end{array}$ \\
\hline
\end{tabular}




\begin{tabular}{|c|l|}
\hline & $\begin{array}{l}\text { - Survival time ranges from zero days (death during investigations) } \\
\text { to seven years (up to time of writing). } \\
\text { - Two patients underwent surgical management, only after } \\
\text { medical management alone had failed. }\end{array}$ \\
\hline Limitations: & $\begin{array}{l}\text { - The study is retrospective, with a small number of cases. } \\
\text { - The study is 23-years old. }\end{array}$ \\
- There is minimal statistical analysis. \\
- There is inconsistent data available for all cases. \\
- Tong-term follow-up is not available for all cases. \\
- Tases only became surgical after medical therapy failed. \\
- The study is based on data from a single hospital.
\end{tabular}

\begin{tabular}{|c|c|}
\hline \multicolumn{2}{|l|}{ Rooney (2002) } \\
\hline Population: & $\begin{array}{l}\text { Twenty-six dogs with pyothorax confirmed by cytological } \\
\text { examination of pleural fluid, or by positive bacterial culture of a } \\
\text { sample of pleural fluid. }\end{array}$ \\
\hline Sample size: & Twenty-six dogs. \\
\hline Intervention details: & $\begin{array}{l}\text { - Seven patients received medical treatment alone (non-invasive } \\
\text { medical management), } 12 \text { patients were treated medically for 2- } \\
\text { to-14 days and then underwent surgery and so were considered } \\
\text { surgical patients, and the remaining seven dogs underwent } \\
\text { surgery within two days of initial presentation. } \\
\text { - All dogs received intermittent thoracic drainage and lavage. }\end{array}$ \\
\hline Study design: & Retrospective single-centre case series. \\
\hline Outcome studied: & $\begin{array}{l}\text { Disease-free interval for patients treated medically and surgically up } \\
\text { to one-year following treatment. }\end{array}$ \\
\hline $\begin{array}{r}\text { Main findings: } \\
\text { (relevant to PICO question): }\end{array}$ & $\begin{array}{l}\text { Patients were disease-free one year following treatment in } 25 \% \\
\text { of medically-managed cases, and } 78 \% \text { of surgically-managed } \\
\text { cases. } \\
\text { - Treatment was } 5.4 \text { times more likely to fail in medically- } \\
\text { managed cases than surgically-managed cases based on disease- } \\
\text { free interval hazard ratio. }\end{array}$ \\
\hline Limitations: & $\begin{array}{l}\text { - The study is retrospective, with a small number of cases. } \\
\text { - The results cover a } 10 \text {-year period. } \\
\text { - The study was performed on data from a single referral teaching } \\
\text { hospital. } \\
\text { - Those patients that underwent late surgery should be } \\
\text { considered as cases of failure of medical therapy. } \\
\text { There is significant variation in treatment administered within } \\
\text { patient groups. }\end{array}$ \\
\hline
\end{tabular}

Stillion (2015)

\begin{tabular}{|r|l|}
\hline Population: & Dogs and cats with pyothorax. \\
\hline Sample size: & Not applicable. \\
\hline
\end{tabular}




\begin{tabular}{|c|c|}
\hline Intervention details: & Not applicable. \\
\hline Study design: & Literature review. \\
\hline Outcome studied: & Not applicable. \\
\hline $\begin{array}{l}\text { Main findings: } \\
\text { (relevant to PICO question): }\end{array}$ & $\begin{array}{l}\text { - Overall survival rate in cases of canine pyothorax is } 83 \% \text { (range } \\
29-100 \% \text { ) in literature published between } 2000 \text { and } 2015 \text {. } \\
\text { - Recurrence rates for dogs and cats range from } 0-14 \% \text {, with risk } \\
\text { factors for recurrence including infection with Nocardia spp or } \\
\text { Actinomyces spp, and inhalation and migration of plant material. } \\
\text { - There is no evidence to suggest reliable characteristics that } \\
\text { accurately predict patient outcome or long-term survival at } \\
\text { initial presentation. } \\
\text { - Antimicrobial therapy in combination with thoracic drainage is } \\
\text { generally accepted as the mainstay of therapy. } \\
\text { - There is a lack of prospective, randomised research. }\end{array}$ \\
\hline Limitations: & $\begin{array}{l}\text { - The review adds nothing new to the literature. } \\
\text { - Very few of the reviewed papers directly compare medical and } \\
\text { surgical management of canine pyothorax. }\end{array}$ \\
\hline
\end{tabular}

\section{Appraisal, application and reflection}

All relevant studies identified that discuss the outcome of medical or surgical management of pyothorax, or directly compare outcomes of both medical and surgical canine pyothorax cases, are either retrospective case series, or literature reviews that do not add new information to the literature. Retrospective case series sit low on the hierarchy of evidence, so meaningful clinical conclusions are difficult to draw.

It appears that many cases across these studies are initially medically managed first before escalating to surgical management adding significant bias to their results, and every surgical case appeared to have received medical (either invasive, non-invasive, or both) treatment, therefore it remains prudent to consider that some surgically managed cases may have recovered with medical management alone. Further to this, it appears that pyothorax aetiology is often the deciding factor when it comes to choice of treatment modality, and this alone may bring about variations in survival rates. There also appears to be a wide range of treatment modalities applied in all studies, even between cases within the same patient groups, and there is rarely any mention of criteria for treatment selection.

It appears from consulting the available literature that invasive medical management (thoracic drainage and lavage via in-dwelling thoracostomy tubes and antimicrobial therapy) and surgical management (in conjunction with antimicrobial therapy) of canine pyothorax provide better long-term survival rates compared to non-invasive medical management (antimicrobial therapy, with or without thoracocentesis) alone. However, until higher quality (prospective, randomised, blinded) research directly comparing standardised medical and surgical management of canine pyothorax is made available, it is difficult to draw meaningful conclusions from the available research.

\section{Methodology Section}

\section{Search Strategy}

Databases searched and dates CAB Abstracts via the Ovid platform, covering from 1973 to 2016 covered: Week 51.

Medline via the Ovid platform, covering from 1946 to 2017. 
Search terms: (dog OR dogs OR canine) AND (empyema OR empyema, pleural OR pleurisy OR pleuritic OR pyothorax)

Dates searches performed: January $8^{\text {th }} 2017$

\section{Exclusion / Inclusion Criteria}

Exclusion: Articles not available in English, single case reports, book chapters, conference proceedings, articles which were not relevant to the PICO question, articles listed on but not provided by the searched databases

Inclusion: Articles available in English which were relevant to the PICO. Articles had to involve more than one animal. Literature reviews were included.

\begin{tabular}{|c|c|c|c|c|c|c|c|c|}
\hline \multirow[b]{2}{*}{ Database } & \multirow[b]{2}{*}{$\begin{array}{c}\text { Number } \\
\text { of } \\
\text { results }\end{array}$} & \multicolumn{7}{|c|}{ Search Outcome } \\
\hline & & $\begin{array}{l}\text { Excluded } \\
\text { - non } \\
\text { English } \\
\text { language }\end{array}$ & $\begin{array}{l}\text { Excluded } \\
\text { - single } \\
\text { case } \\
\text { report }\end{array}$ & $\begin{array}{l}\text { Excluded } \\
\text { - book } \\
\text { chapter }\end{array}$ & $\begin{array}{l}\text { Excluded - } \\
\text { conference } \\
\text { proceedings }\end{array}$ & $\begin{array}{c}\text { Excluded } \\
\qquad- \\
\text { irrelevant } \\
\text { to PICO }\end{array}$ & $\begin{array}{c}\text { Excluded } \\
\text { - paper } \\
\text { not } \\
\text { accessible }\end{array}$ & $\begin{array}{c}\text { Total } \\
\text { relevant } \\
\text { papers }\end{array}$ \\
\hline $\begin{array}{l}\text { CAB } \\
\text { Abstracts }\end{array}$ & 183 & 58 & 2 & 4 & 5 & 98 & 3 & 13 \\
\hline Medline & 139 & 19 & 1 & 0 & 0 & 106 & 1 & 12 \\
\hline Total rele & & hen dupl & es rem & & & & & 13 \\
\hline
\end{tabular}

\section{CONFLICT OF INTEREST}

The authors declare no conflicts of interest.

\section{REFERENCES}

1. Bach, J.F. Balakrishnan, A. (2015) Retrospective comparison of the costs between medical and surgical treatment of canine pyothorax. Canadian Veterinary Journal, 56 (11) pp. 1140-1143.

2. Boothe, H.W. et al. (2010) Evaluation of outcomes in dogs treated for pyothorax: 46 cases (19832001). Journal of the American Veterinary Medical Association, 236 (6), pp. 657-663. http://dx.doi.org/10.2460/javma.236.6.657

3. Demetriou, J.L. et al. (2002) Canine and feline pyothorax: a retrospective study of 50 cases in the UK and Ireland. Journal of Small Animal Practice; 43 (9) pp. 388-394.

4. Frendin, J. (1997) Pyogranulomatous pleuritis with empyema in hunting dogs. Zentralb/ Veterinarmed A, 44 (3), pp. 167-178. http://dx.doi.org/10.1111/j.1439-0442.1997.tb01098.x 
5. Johnson, M.S. Martin, M.W.S (2006) Successful medical treatment of 15 dogs with pyothorax. Journal of Small Animal Practice, 48 (1), pp. 12-16.

6. Lee, K.C.L (2014) Surgical or medical management of pyothorax in dogs? Veterinary Record, 174 (24), pp. 605-606. http://dx.doi.org/10.1136/vr.g3817

7. MacPhail, C.M (2007) Medical and Surgical Management of Pyothorax. Veterinary Clinics of North America, 37 (5), pp. 975-988. http://dx.doi.org/10.1016/i.cvsm.2007.05.012

8. Meakin, L.B. et al. (2013) Prevalence, outcome and risk factors for postoperative pyothorax in 232 dogs undergoing thoracic surgery. Journal of Small Animal Practice, 54 (6) pp. 313-317. http://dx.doi.org/10.1111/isap.12064

9. Mellanby, R.J. Villiers, E. Herrtage, M.E. (2002) Canine pleural and mediastinal effusions: a retrospective study of 81 cases. Journal of Small Animal Practice, 43 pp. 447-451.

10. Piek, C.J. Robben, J.H. (2000) Pyothorax in nine dogs. The Veterinary Quarterly, 22 (2), pp. 107-111. http://dx.doi.org/10.1080/01652176.2000.9695035

11. Robertson, S.A. et al. (1983) Thoracic empyema in the dog: a report of twenty-two cases. Journal of Small Animal Practice, 24 (2), pp. 103-119. http://dx.doi.org/10.1111/j.1748-5827.1983.tb00419.x

12. Rooney, M.B. Monnet, E. (2002) Medical and surgical treatment of pyothorax in dogs: 26 cases (19912001). Journal of the American Veterinary Medical Association, 221 (1), pp. 86-92.

13. Stillion, J.R. Letendre, J.A. (2015) A clinical review of the pathophysiology, diagnosis, and treatment of pyothorax in dogs and cats. Journal of Veterinary Emergency and Critical Care, 25 (1), pp. 113-129.

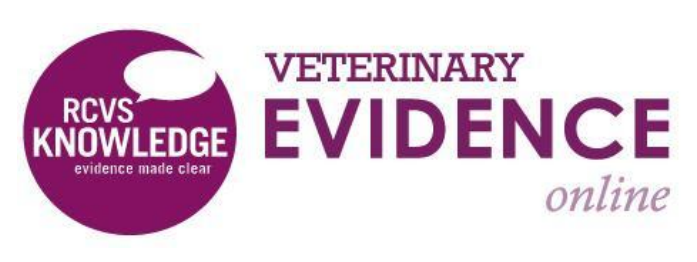

\footnotetext{
Intellectual Property Rights

Knowledge Summaries are a peer-reviewed article type which aims to answer a clinical question based on the best available current evidence. It does not override the responsibility

of the practitioner. Informed decisions should be made by considering such factors as individual clinical expertise and judgement along with patient's circumstances and owners' values. Knowledge Summaries are a resource to help inform and any opinions expressed within the Knowledge Summaries are the author's own and do not necessarily reflect the view of the RCVS Knowledge.

Authors of Knowledge Summaries submitted to RCVS Knowledge for publication will retain copyright in their work, but will be required to grant to RCVS Knowledge an exclusive license of the rights of copyright in the materials including but not limited to the right to publish, re-

publish, transmit, sell, distribute and otherwise use the materials in all languages and all media throughout the world, and to license or permit others to do so.
} 
Veterinary Evidence and EBVM Network are RCVS Knowledge initiatives. For more information please contact us at

\section{editor@veterinaryevidence.org}

RCVS Knowledge is the independent charity associated with the Royal College of Veterinary Surgeons (RCVS). Our ambition is to become a global intermediary for evidence based veterinary knowledge by providing access to information

that is of immediate value to practicing veterinary professionals and directly contributes to evidence based clinical decision-making.

\section{www.veterinaryevidence.org}

RCVS Knowledge is a registered Charity No. 230886 Registered as a Company limited by guarantee in England and Wales No. 598443.

Registered Office:

Belgravia House

62-64 Horseferry Road London SW1P 2AF

This work is licensed under a Creative Commons Attribution 4.0 International License 